Disponível em:

http://editora.unoesc.edu.br/index.php/race

RACE, Joaçaba, v. 16, n. 3, p. 1161-1184, set./dez. 2017

\title{
MECHANISMS OF CORPORATE GOVERNANCE AND PERFORMANCE: ANALYSIS OF PUBLIC COMPANIES LISTED IN BM\&FBOVESPA
}

\author{
Mecanismos de governança corporativa e desempenho: análise das companhias do \\ subsetor de utilidade pública listadas na \\ BM\&FBovespa
}

Josimar Pires da Silva

E-mail: josimarnx@yahoo.com.br Mestre em Ciências Contábeis pela Universidade de Brasília; Doutorando em Ciências Contábeis pela Universidade de Brasília.

Mariana Pereira Bonfim

E-mail: marianapbonfim@gmail.com Mestre em Ciências Contábeis pela Universidade do Estado do Rio de Janeiro; Doutoranda em Ciências Contábeis pela Universidade de Brasília; Professora no Departamento de Ciências Contábeis da Universidade Federal Fluminense.

Rafael Martins Noriller

E-mail: rafael.mnoriller@gmail.com

Mestre em Administração pela Universidade Federal de Mato Grosso do Sul; Doutorando em Ciências Contábeis pela Universidade de Brasília; Professor na Universidade Federal da Grande Dourados.

Endereço para contato: Rua João Rosa Góes, 1761, Vila Progresso, 79825-070, Dourados, Mato Grosso do Sul, Brasil.

Carlos Vicente Berner

E-mail: carlosvberner@hotmail.com Mestre em Ciências Contábeis pela Fundação Escola de Comércio Álvares Penteado; Doutorando em Ciências Contábeis pela Universidade de Brasília; Professor na Universidade Federal do Tocantins.

Artigo recebido em 06 de dezembro de 2016. Aceito em 19 de junho de 2017. 
The objective of this research is to verify the level of relationship between the mechanisms of corporate governance and the performance of the companies of the public subsector, listed on BM\&FBovespa. The research was based on the financial statements from 2010 to 2014, obtained on the BM\&FBovespa website, resulting in a sample of 63 companies with 315 observations. In order to calculate the performance proxy of the company, the ROA was used, and for the calculation of the proxies of the corporate governance mechanisms were used for the quality of the audit, the concentration of ownership in common shares and preferred shares, participation in the levels of governance of BM\&FBovespa, number of shares held by the government and number of directors in the Board, adapted from the Mollah and Zaman (2015) survey. Convergence with national and international research, the findings of the study showed that such variables as quality of profit, concentration of ownership in preferred shares, participation in governance levels and size of the Board are positively related to the performance of the company; already a concentration of ownership in common shares and number of shares held by the government are negatively related to performance. For future reference, it is recommended to expand other sectors of the market as well as to use other mechanisms of corporate governance, presented in the literature.

Keywords: Corporate Governance. Performance. Public Subsector.

\section{Resumo}

O objetivo da pesquisa foi o de verificar o nível de relação entre os mecanismos de governança corporativa e o desempenho das empresas do subsetor de utilidade pública, listadas na BM\&FBovespa. A pesquisa teve como base os dados das demonstrações financeiras de 2010 a 2014, obtidas no sítio eletrônico da BM\&FBovespa, resultando assim, em uma amostra de 63 empresas, com 315 observações. Para o cálculo da proxy de desempenho da empresa foi utilizado o ROA, e para o cálculo das proxies dos mecanismos de governança corporativa foram utilizadas a qualidade da auditoria, concentração de propriedade em ações ordinárias e em ações preferenciais, participação nos níveis de governança da BM\&FBovespa, número de ações mantidas pelo governo e número de diretores no Conselho, adaptado da pesquisa de Mollah e Zaman (2015). Convergente com pesquisas nacionais e internacionais, os achados desse estudo evidenciaram que as variáveis qualidade do lucro, concentração de propriedade em ações preferenciais, participação nos níveis de governança e tamanho do Conselho são positivamente relacionados com o desempenho da empresa; já a concentração de propriedade em ações ordinárias e o número de ações mantidas pelo governo são negativamente relacionadas com o desempenho. Para pesquisas futuras, recomenda-se ampliar a outros setores do mercado bem como utilizar outros mecanismos de governança corporativa, presentes na literatura.

Palavras-chave: Governança Corporativa. Desempenho. Utilidade Pública. 


\section{INTRODUCTION}

The previous literature has highlighted a wide range of mechanisms related to corporate governance, especially in research at an international level (CHANEY; FACCIO; PARSLEY, 2011; CHEN, 2016; CHOI; LEE; PARK, 2013; EL-SAYED EBAID, 2013; GUL; SRINIDHI; NG, 2011; HAZARIKA; KARPOFF; NAHATA, 2012; ISIK; INCE, 2016; JIZI et al., 2014; MACEDO; CORRAR, 2012; MOLLAH; ZAMAN, 2015; RODRIGUEZ-FERNANDEZ; FERNANDEZ-ALONSO; RODRIGUEZ-RODRIGUEZ, 2014; SÁENZ GONZÁLEZ; GARCÍA-MECA, 2014; ZIAEE, 2014). Among these, we highlight quality of audit, board composition, number of board members, duality of roles, government participation in the voting capital and cash flows, equity participation of managers and board members, ownership structures (right to vote, right to cash flows, difference between voting capital and cash flows), participation of financial institutions in the voting capital and compensation in the form of employee stock options (ATHANASAKOU; OLSSON, 2012; ELSAYED EBAID, 2013; HAZARIKA; KARPOFF; NAHATA, 2012; JIZI et al., 2014; RAJGOPAL; VENKATACHALAM, 2011; SÁENZ GONZÁLEZ; GARCÍA-MECA, 2014; SHIRI et al., 2012).

The effectiveness of corporate governance in overseeing the financial reporting process is essential for the preservation of investors and the confidence in capital markets. It is expected that better corporate governance mechanisms lead to a better understanding of the reliability of the company's performance by investors measured by profit (EL-SAYED EBAID, 2013). Corporate governance, at the beginning of this century, after the collapse of large companies such as Enron (world's largest energy company) and WorldCom (world's largest telecommunications company), has taken a new dimension in the business scenario, where it is expected that the application of corporate governance principles promotes information with a greater persistence, and that this information reverberates in financial markets in order to encourage investment. Thus, under the proposed mechanisms for corporate governance, there is expectation that they be able to reduce agency costs, limit the opportunistic behavior of management, leading to an improved quality and reliability of information, and also increase the value of the company (SHIRI et al., 2012).

Corporate governance mechanisms have been linked to several accounting measurements such as company performance. The results are mixed. Some studies have shown evidence that governance mechanisms impact positively on the results of companies (KARAMANOU; VAFEAS, 2005; ZIAEE, 2014; SHIRAI, 2004; TIAN; 
ESTRIN, 2008; BOUBRAKI et al., 2011; MIGUEL; PINDADO; TORRE, 2004). Moreover, Xu and Wang (1999), Qi, Wu and Zhang (2000), Sun and Tong (2003), and Bai et al. (2004) found a negative correlation between corporate governance and performance.

It is expected for the Public Utility sector - the one with the greatest representation among the sectors listed in the BM\&FBovespa regarding the number of companies, i.e., 73 - the use of good corporate governance mechanisms because the ownership of a public utility title confers prestige and credibility to the extent that it can be considered as a proof for an official recognition of services rendered by the entity. In addition, other direct benefits are the ability to receive grants from the Union and its state companies, the possibility, for income tax collection purposes, for the donor (entity) to deduct from its gross income the contributions made to public utility entities according to the Law no. 9.249/95, and tax immunity.

Thus, the following stands out as a research problem: What is the level of relation between performance and corporate governance of Brazilian public companies listed in the "public" sub-sector of BM\&FBovespa? In order to answer this question, this research aims to analyze the level of relation between corporate governance and performance of public companies listed in the BM\&FBovespa. To achieve this general objective, this research has the following objectives: (a) demonstrate the link between performance and audit quality, (b) stress the relation between performance and government participation in the voting capital, (c) demonstrate the links between performance and participation in corporate governance standards of BM\&FBovespa, (d) demonstrate the links between performance and ownership structure, and (e) demonstrate the links between performance and board size.

Until the research, no studies in the Brazilian context were found that investigated the relation between corporate governance mechanisms and the performance of companies in the public utilities sector, especially quality of audit, government participation in the voting capital, participation in the corporate governance levels of BM\&FBovespa, ownership structure and board size.

Studies related to corporate governance are timely, especially in view of an international relevance specifically in developed countries, e.g. USA and some European Union countries, where such relations have been stressed and notably drawing the attention of universities. Few studies have analyzed it in developing countries such as Brazil.

Another motivation for the study is the public utility sector itself, which is poorly researched in the accounting literature. However, it has a high prominence 
especially due to a great number of companies among those listed, to regulation for they meet part of the basic needs of the population and to representation, with a high number of companies among the sectors listed in BM\&FBovespa.

\section{LITERATURE REVIEW AND HYPOTHESES}

Information on the company's characteristics, financial position and performance are useful to users in the current assessment and in making future estimates particularly about future cash flows. However, managers may use such discretionary choices opportunistically because of a possible link between their salary and the results and also because of other factors, e.g. the company's other contracts. They may use such criterion to enhance the informational value of accounting information (especially profit) to eventually disclose to investors the long-term performance of the company (CHANEY; FACCIO; PARSLEY, 2011).

Accounting frauds discovered in the capital markets confirm the existence of ethical lapses and evidence the importance of transparency and reliability of financial information provided to the market (LANG; LUNDHOLM, 2000). The regulatory response to financial scandals has been taking steps to protect the transparency of information, mitigate conflicts of interest and ensure the independence of auditors, all in order to protect the interests of investors and increase the confidence of capital markets (LEUZ; NANDA; WYSOCKI, 2002).

The use of good corporate governance mechanisms tend to reduce information asymmetry between shareholders and managers, reducing the control rights which they, together with creditors, assign to managers, enabling the increase in the probability of investment projects by managers that maximize shareholders' wealth (SHLEIFER; VISHNY, 1997). Companies with a weak corporate governance are more likely to manage results in order to meet or surpass analysts' forecasts (SHIRI et al., 2012). In the absence of any effects of corporate governance, it is expected the profit quality to be low (ATHANASAKOU; OLSSON, 2012).

Previous studies have highlighted the relation between corporate governance mechanisms and business performance (SILVEIRA, 2004; ISIK; INCE, 2016; MACEDO; CORRAR, 2012; MOLLAH; ZAMAN, 2015; RODRIGUEZ-FERNANDEZ, FERNANDEZ-ALONSO; RODRIGUEZ-RODRIGUEZ, 2014; ZIAEE, 2014). A great part of the literature investigates the relations between governance mechanisms and company performance, including shareholder value of non-financial companies (STANWICK; STANWICK, 2010; WEIR et al., 2002). The empirical evidence is 
however mixed (BAUER et al., 2008; GANI; JERMIAS, 2006; LARCKER et al., 2007; STANWICK; STANWICK, 2010). A number of studies reported positive effects of corporate governance on the value of non-financial companies (e.g., LEE et al., 1992). Hutchinson (2002), for example, reported a negative association between corporate governance and company value, while Gupta et al. (2009) did not think corporate governance affects the company's value.

Such studies have shown the impacts of various corporate governance mechanisms on the performance and quality of profit, among which the following may be mentioned: number of board members, number of shares held by the government, percentage of participation of the majority ordinary shareholder, percentage of preferred shares of the majority ordinary shareholder, quality of audit (Big Four), and participation in the governance levels of Bovespa.

\subsection{DEVELOPMENT OF HYPOTHESES}

This section proposes to develop research hypotheses about the impacts of several corporate governance mechanisms on the performance of companies listed in BM\&FBovespa.

\subsubsection{AudQua (Audit Quality)}

An external audit conducted in accordance with high quality auditing standards can promote the implementation of accounting standards by entities and helps to ensure that its financial statements are reliable, transparent and useful to the market, thereby increasing confidence. In addition, quality audits can help to reinforce a strong corporate governance, risk management and internal controls in companies, thereby contributing to financial stability (ZIAEE, 2014).

Karamanou and Vafeas (2005) found that the financial expertise of audit committees is associated with a greater likelihood of management gains, more informative good news forecasts and more positive reactions from the stock market to management forecasts. Krishnan (2005) shows that audit committees with financial experience are significantly less likely to be associated with the incidence of internal control problems. In addition, Krishnan and Visvanathan (2009) found that auditors charge lower rates for companies when their audit committees have financial experts. In this context, the following hypothesis is confirmed: 
H1: There is a significant and positive relation between audit quality and performance of public companies listed in BM\&FBOVESPA, ceterius paribus.

\subsubsection{GOVERNMENT SHAREHOLDING}

Existing empirical studies have reported mixed results on this issue. For example, Xu and Wang (1999), Qi, Wu and Zhang (2000), Sun and Tong (2003), and Bai, Liu, Lu, Song, Zhang (2004) found a negative correlation between government shareholding and company performance. Chen and Gong (2000) found a positive correlation. Shirai (2004) and Tian and Estrin (2008) argue that there may be a U-shaped relation between government shareholding and performance.

Li, Sun and Zou (2009) found that government shareholding has a significant negative relation with the performance of companies when they are sufficiently profitable. In other words, while the government still seems to exert a strong influence on the performance of partially privatized companies, the quantitative relation between government shareholding and company performance is nonlinear and asymmetric. Thus, the following hypothesis is confirmed:

H2: There is a significant negative relation between the number of shares held by the government and the performance of public companies listed in BM\&FBOVESPA, ceterius paribus.

\subsubsection{Ownership Structure - Proportions of common shares of the majority shareholder}

Shareholders with a great participation in the voting capital play an important role in the internal control of companies because the volume of participation encourages them to monitor and influence the strategy of the company in which they invested capital (GABRIELSEN; GRAMLICH; PLENBORG 2002; YEO et al., 2002). This means that a higher concentration of property must be in accordance with the hypothesis of efficient monitoring (JENSEN; MECKLING, 1976) and must lead to a less opportunistic behavior and a greater tendency to maximize the value of the company (FAMA; JENSEN, 1983; FAMA, 1980), thus affecting positively the informativeness of accounting profits since the increase in the participation of the controlling shareholder reduces this owner's incentives to expropriate the wealth from minority shareholders (BOUBRAKI et al., 2011; MIGUEL; PINDADO; TORRE, 2004). In 
this sense, De Bos and Donker (2004) stress that increased ownership concentration is a CG mechanism effective in monitoring accounting decisions made by management.

La Porta et al. (1998) point out that, in most developing economies, there is a high level of ownership concentration. A simple ownership concentration measure can be obtained by the percentage of shares held by shareholders of a group of companies (LEFORT, 2005). Regarding the Brazilian reality, many authors distinguish the ownership structure based on voting rights and the participation in cash flows (SILVEIRA et al., 2007; SILVEIRA; BARROS, 2008). The higher the percentage of common shares held by the controller, the greater the possibility of expropriation from outside shareholders. This could lead to a worse level of corporate governance as a result of the concentration of control rights. On the other hand, a higher concentration of control rights could cause the company to adopt best corporate governance practices in order to offset the increased possibility of expropriation. Thus, the following hypothesis is confirmed:

H3: There is a significant negative relation between Ownership Structure proportions of common shares of the majority shareholder - and performance of public companies listed in BM\&FBOVESPA, ceterius paribus.

\subsubsection{Ownership Structure - Proportions of preferred shares of the majority shareholder}

As for the percentage of total shares held by the controller, the higher the percentage, the lower the possibility of expropriation due to a greater participation of the controlling shareholder in cash flow rights. However, this could also lead to a worse level of corporate governance, as the controller participation itself in the total capital could be seen as a governance mechanism that would reduce the company's need to adopt better corporate governance practices (SILVEIRA; BARROS, 2008).

In general, regarding Brazilian companies, the higher the percentage of common shares owned by the controller, the higher the possibility of expropriation from minority shareholders and the worse the level of corporate governance, in thesis. On the other hand, the higher the participation of this same shareholder in cash flows, the lower the possibility of expropriation from minority shareholders. The higher the concentration of preferred shares by the controller, the lower the expropriation from outside shareholders (SILVEIRA, 2004). Thus, the following hypothesis is confirmed: 
H4: There is a significant positive relation between Ownership Structure proportions of preferred shares of the majority shareholder - and performance of public companies listed in BM\&FBOVESPA, ceterius paribus.

\subsubsection{Participation in the levels of corporate governance of BM\&FBovespa}

Companies that adhere to different levels of Bovespa's Corporate Governance must comply with the strictest standards of governance and must provide, on average, better control mechanisms for aligning the interests of managers, mainly when compared to other companies in their country of origin (SILVEIRA; BARROS, 2008; SILVEIRA; PEROBELLI; BARROS, 2008).

Companies that voluntarily adhere to special segments of Corporate Governance of BM\&FBovespa, especially Level 2 and New Market, should commit to a greater transparency and CG standards. Therefore, such companies should present a better CG at the company level than the companies listed in the traditional listing segments (SILVEIRA et al., 2007). Overall, several studies state that good corporate governance practices improve company performance (ISIK; INCE, 2016; MACEDO; CORRAR, 2012). In this context, the following hypothesis is confirmed:

H5: There is a significant and positive relation between adhesion to corporate governance levels of BM\&FBOVESPA and performance of public companies listed in BM\&FBOVESPA, ceterius paribus.

\subsubsection{Board Size}

Studies such as Dâvila and Watkins (2009) and Correia et al. (2011) found that, if a board is too small, the monitoring of the management team is low. Therefore, directors tend to greater discretion in receiving a higher pay and a higher chance of earnings management. They are also more prone to information asymmetry (BRICK; PALMON; WALD, 2006; ANDRES; AZOFRA; LOPEZ, 2005). Thus, a larger size of the Board of Directors results in a better monitoring of the management team and in a higher quality of corporate decisions (PEARCE; ZAHRA, 1992).

Most studies suggest a negative association between board size and company performance. Board size is negatively related to the value of the company due 
to the fact that companies with larger boards of directors tend to use their assets in a less efficiently way and profit less (YERMACK, 1996). For example, Jensen (1993) suggests that a limited number of board members is important for an effective corporate governance. Hermalin and Weisbach (2003) reported that board size is negatively associated with company performance and quality of decision-making. Mak and Kusnadi (2005) found that board size has a negative impact on the company's value in Singapore and Malaysia. Guest (2009) concludes that board size has a strong negative effect on company profitability when measured by Tobin's Q and stock returns.

O’Connell and Cramer (2010) show a negative association between board size and performance when measured by ROA and Tobin's Q for companies listed in the Irish stock market. Gill and Mathur (2011) found a negative relation between board size and company profitability. Nguyen et al. (2014) concluded that board size has a significantly negative influence on company performance after endogeneity emission control. On the other hand, based on non-financial business samples, Boone et al. (2008), Coles et al. (2008), Linck et al. (2008) and Lehn et al. (2009) concluded that some companies might benefit from larger boards of directors. A study conducted by Isik and Ince (2016) found a positive relation between the board size and financial performance of financial institutions. Thus, the following hypothesis is confirmed:

H6: There is a significant and positive relation between number of directors in the board of directors and performance of public companies listed in BM\&FBOVESPA, ceterius paribus.

\section{METHODOLOGY}

To achieve the purpose of this study, information from corporate financial statements was collected from the Economática ${ }^{\circledR}$ database and from the BM\&FBOVESPA website obtained through the EmpresasNet external disclosure software.

Initially, the sample consisted of 73 Public companies: 64 companies in the electricity sub-sector, two companies in the gas sub-sector and seven companies in the water and sanitation sub-sector. Data were from 2010 to 2014, i.e., a period of 5 consecutive years. The final sample comprised 63 companies, which was justified by the exclusion of 10 companies that lacked the information necessary for research on financial statements, i.e., 315 companies/year.

To calculate the regression of the dependent variable (1), audit quality, concentration of ownership of common shares, concentration of ownership of preferred shares, participation in the governance levels of Bovespa, number of shares held by the government, and number of directors in the board were used and adapted from the work by Mollah and Zaman (2015) according to the data model shown in the following equation: 
$\mathrm{ROA}_{i, t}=\beta_{0}+\beta_{1} A U D Q U A_{i, t}+\beta_{2}$ OWNCON $_{i, t}+\beta_{3} O W N P R O P_{i, t}+\beta_{4}$ BOV $_{i, t}+$ $\beta_{5} G_{O V T}+\beta_{i, t} \beta_{6} S I Z E_{i, t}+\varepsilon_{i, t}$

Where:

ROA = Operating profit divided by average assets

AUDQUA = Audit quality, dummy variable with value "1" if Big Four or otherwise " 0 ".

OWNCON = Concentration of ownership, percentage of common shares of the majority shareholder.

OWNPROP = Concentration of ownership, percentage of preferred shares of the majority shareholder.

$\mathrm{BOV}=$ Participation in the levels of corporate governance of BM\&FBovespa

GOVT = Number of shares held by the government divided by the total number of common shares.

BSIZE $=$ Number of board directors.

The variables, expected signs and justifications are summarized in Board 1.

Board 1 - Justification of variables

\begin{tabular}{|c|c|c|}
\hline Variables & $\begin{array}{l}\text { Expected relation } \\
\text { between variables } \\
\text { and the ROA }\end{array}$ & Justification \\
\hline $\begin{array}{l}\text { AuditQuality } \\
\text { (AUDQUA) }\end{array}$ & Positive & $\begin{array}{l}\text { The quality of the audit is critical to the company's } \\
\text { financial performance; positive relation (ZIAEE et } \\
\text { al., 2014). }\end{array}$ \\
\hline $\begin{array}{l}\text { Structure of common } \\
\text { Shares Ownership } \\
\text { (OWNCON) }\end{array}$ & Negative & $\begin{array}{l}\text { In theory, the higher the concentration of common } \\
\text { shares, the higher the possibility of expropriation } \\
\text { from outside shareholders (SILVEIRA, 2004). }\end{array}$ \\
\hline $\begin{array}{l}\text { Structure of } \\
\text { Preferred Shares } \\
\text { Ownership } \\
\text { (OWNPROP) }\end{array}$ & Positive & $\begin{array}{l}\text { The higher the concentration of preferred shares } \\
\text { by the controller, the lower the expropriation from } \\
\text { outside shareholders (SILVEIRA, 2004). }\end{array}$ \\
\hline $\begin{array}{l}\text { Governance Level } \\
\text { (BOV) }\end{array}$ & Positive & $\begin{array}{l}\text { Several studies state that good corporate governan- } \\
\text { ce practices improve company performance (MA- } \\
\text { CEDO; CORRAR, 2012; OZCAN; INCE, 2016). }\end{array}$ \\
\hline $\begin{array}{l}\text { Government Sha- } \\
\text { reholding (GOVT) }\end{array}$ & Negative & $\begin{array}{l}\text { Xu and Wang (1999), Qi, Wu and Zhang (2000), } \\
\text { Sun and Tong (2003), and Bai et al. (2004) found } \\
\text { negative correlations between government sha- } \\
\text { reholding and company performance. }\end{array}$ \\
\hline $\begin{array}{l}\text { Board Size } \\
\text { (BSIZE) }\end{array}$ & Positive & $\begin{array}{l}\text { Positive relations between board size and financial } \\
\text { performance of financial institutions (ISIK: INCE, } \\
\text { 2016). }\end{array}$ \\
\hline
\end{tabular}

Source: the authors. 


\subsection{RESEARCH LIMITATIONS}

The choice of the variable Return on Assets [ROA] - operating profit divided by average assets - at the expense of other variables such as proxy for performance. It is noted that this variable aims to assess the manager's efficiency in using assets to generate profits. Thus, the results cannot be extrapolated to other company performance metrics.

Likewise, the independent variables measure the impacts of audit, ownership structure, participation in different levels of BM\&FBovespa, government participation in the voting capital and board size on the performance of companies. The results are limited to these corporate governance indicators and cannot be extrapolated to others.

Another limitation is that the study's findings refer to companies in the Public Utility sector driven by a strong regulation. Therefore, they cannot be generalized for other companies belonging to other sectors listed in BM\&FBovespa.

\section{ANALYSIS OF RESULTS}

In order to verify the relations between quality of profits and corporate governance, company performance was used as Proxy for profit quality, represented by the variable ROA (company net income divided by average assets), as established by Mollah and Zaman (2015).

Table 1 shows descriptive statistics of the other variables, in which the results show that (a) an average of $58 \%$ of the surveyed companies are audited by independent auditor companies, considered as Big Four, which indicates that more than half of the analyzed companies have a high-quality audit; (b) on average, boards are composed of 10 directors, 85\% of which are non-executives of the company; and (c) approximately $38 \%$ of the researched companies have adhered to at least one of the special segments of corporate governance of BM\&FBovespa. 
Table 1 - Descriptive statistics

\begin{tabular}{llrrrr}
\hline \multicolumn{1}{c}{ Variables } & \multicolumn{1}{c}{ Mean } & \multicolumn{1}{c}{ Median } & Maximum & \multicolumn{1}{c}{ Minimum } & Standard Deviation \\
\hline ROA & 0.063235 & 0.101710 & 3.082896 & -4.34720 & 0.405937 \\
AUDQUA & 0.582010 & 1.000000 & 1.000000 & 0.000000 & 0.493882 \\
OWNCON & 0.726050 & 0.7366 & 1.000000 & 0.157 & 0.251875 \\
OWNPROP & 0.231906 & 0.000000 & 1.000000 & 0.000000 & 0.363276 \\
BOV & 0.317460 & 0.000000 & 1.000000 & 0.000000 & 0.466105 \\
GOVT & 0.329834 & 0.038 & 1.000000 & 0.000000 & 0.384378 \\
BSIZE & 10.92063 & 9 & 30 & 3 & 6.775603 \\
\hline
\end{tabular}

Source: the authors.

Table 2 shows the correlation coefficients between the variables used in the research: the highest-value relation is between the variables OWNCON and BOV (-0.5341). However, it was not necessary to adjust the model variables. Additionally, a multicollinearity test was performed using Variance Inflation Factor (VIF) in order to verify whether a variable is a linear combination of two or more variables of the model. The result (not tabulated) evidenced values below 10, which proves that there is no multicollinearity among the variables.

Table 2 - Correlation matrix

\begin{tabular}{lrrrrrr}
\hline Variables & AUDQUA & BOV & BSIZE & GOVT & OWNCON & OWNPROP \\
\hline AUDQUA & 1 & & & & & \\
BOV & 0.2207 & 1 & & & \\
BSIZE & 0.2635 & 0.2347 & 1 & & \\
GOVT & 0.0572 & 0.1834 & 0.3504 & 1 & 1 \\
OWNCON & -0.0085 & -0.5341 & -0.1115 & -0.0416 & \\
OWNPROP & -0.0408 & -0.3817 & -0.2213 & -0.2648 & 0.4293 & \\
Source: the authors. & & & & &
\end{tabular}

In addition, the basic assumptions of OLS regression (normality, homoscedasticity and autocorrelation of residues) were also analyzed by Jarque-Bera test, White test, Breusch-Pagan-Godfrey test and Durbin-Watson test. The tests indicated that the residues follow a normal distribution, that there is no autocorrelation among residues and that they are homoscedastic, which meets the assumptions of linear regression. 
The model used to process the panel data was obtained using the pooled approach. The results are shown in Table 3.

Table 3 - Regression analysis of Corporate Governance and Performance variables

\begin{tabular}{lcrrr}
\hline Variable & Coefficient & Standard Error & T statistic & p-value \\
\hline CONST & 0.056725 & 0.006687 & 8.482347 & 0.0000 \\
AUDQUA & 0.011336 & 0.003663 & 3.095017 & 0.0021 \\
OWNCON & -0.028935 & 0.010986 & -2.633804 & 0.0089 \\
OWNPROP & 0.058165 & 0.009566 & 6.080263 & 0.0000 \\
BOV & 0.002645 & 0.002821 & 0.937680 & 0.3491 \\
GOVT & -0.152371 & 0.006537 & -23.31038 & 0.0000 \\
BSIZE & 0.006497 & 0.000431 & 15.06559 & 0.0000 \\
R & 0.130497 & & & \\
Adjusted R & 0.095007 & & & \\
F statistic & 3.677026 & & & \\
P-value (Est. F) & 0.000135 & & & \\
\hline SOurce: & & & & \\
\hline
\end{tabular}

Source: the authors.

Dependent Variable: Company performance (ROA). Independent variables: Audit Quality (AUDQUA), Structure of Common Shares Ownership (OWNCON), Structure of Preferred Shares Ownership (OWNPROP), Governance level of BM\&FBovespa (BOV), Government Shareholding (GOVT), and Board Size (BSIZE).

Regression data evidenced that the variable AUDQUA showed a significant coefficient at $1 \%(\mathrm{p}$-value $=0.00)$ and a positive coefficient regarding the dependent variable (ROA), thus confirming the hypothesis that companies audited by an independent audit company among the so-called Big Four, thus presenting a better quality of the performed audit, also performed better. Thus, the first research hypothesis was confirmed, indicating that there is a significant and positive relation between quality of audit and the performance of the companies surveyed.

The second research hypothesis, which seeks to determine the existence of a significant negative relation between the number of shares held by the government and the performance of the companies surveyed, was confirmed: the variable GOVT was statistically significant ( $\mathrm{p}$-value $=0.00$ ), especially with a negative coefficient. Thus, for the sample of companies surveyed, the higher the number of shares held by the government, the worse the performance of the company. 
The variable OWNCON showed a negative significant coefficient at $1 \%$ ( $\mathrm{p}$-value $=0.00)$, confirming the third research hypothesis, which indicates that there is a significant negative relation between the company's ownership structure (proportions of common shares of the majority shareholder) and its performance. That is, the higher the number of shares the controller shareholder holds, the worse the performance of the company.

On the other hand, the concentration of preferred shares was also studied. It showed a positive coefficient and a statistical significance ( $p$-value $=0.00$ ). This indicates that the higher the concentration of preferred shares by the controlling shareholder, the greater the performance of the company. According to a study by Silveira (2004), which also showed the same tendency, this positive relation is due to the existence of a lower expropriation from outside shareholders.

The variable BOV showed no significance, with a p-value of 0.3491 . However, when analyzing only the meaning of the coefficient, it can be noticed that it showed the initially expected signs, that is, companies that are listed in at least one governance segment of the BM\&FBovespa also performed better. This was also observed by other studies such as those conducted by Macedo and Corrar (2012) and Ozcan and Ince (2016), who also showed that good governance practices improve company performance.

Regarding the variable BSIZE, the same statistically significance (p-value $=0.00$ ) and positive coefficient were observed. This corroborates the sixth research hypothesis, according to which there is a positive and significant relation between the size of the board of directors and company performance. Consistent with the works by Pearce and Zahra (1992) and Isik and Ince (2016), a larger Board of Directors has a better oversight of management and, consequently, a better quality of business decisions, resulting in a higher company performance.

\section{CONSIDERATIONS AND RECOMMENDATIONS}

The purpose of this research was to investigate the relations between performance and corporate governance of companies in the sub-sector "public company" listed in the BM\&FBOVESPA.

In order to verify performance and corporate governance, the variable ROA (net income divided by average assets) was used with the following independent variables: (a) quality of audit (AUDQUA), (b) structure of common shares ownership 
(OWNCON), (c) structure of preferred shares ownership (OWNPROP), (d) level of governance (BOV), (e) government shareholding (GOVT), and (f) board size (BSIZE).

Initial results showed that the analyzed companies have auditing quality, government participation and institutional shareholdings. The variable quality of audit presented significant coefficients, indicating that companies that were audited independently by the so-called Big Four showed a higher audit quality as well as a higher performance.

This confirms the significant negative relation between the number of shares held by the government and the performance of the companies surveyed. It was verified by the GOVT variable, which showed a negative coefficient. Therefore, it is noteworthy that the higher the number of shares held by the government, the lower the performance of the company. On the other hand, upon confirming the third hypothesis, it is concluded that if there is a high number of shares held by the shareholder, there will be a negligible company performance.

Upon dealing with the concentration of preferred shares, it was observed that the coefficients had significant positive results, indicating that the higher the concentration of preferred shares by the controller, the better the performance of the company. In the analysis, it was found that the variable level of governance was not significant. However, when analyzing only the coefficient level, it is expected that companies listed in any governance segment of BM\&FBovespa perform better. There was also a significant positive relation, confirming the sixth hypothesis, which posits a significance between board size and company performance.

In sum, the findings of the research are related to those found in international and national studies, as already highlighted for the determining of the hypotheses, ceteris paribus.

It is recommended that further research on performance versus corporate governance be conducted with other sectors and other corporate governance mechanisms in addition to those of this research.

\section{REFERENCES}

ANDRES, P. de; AZOFRA, V.; LOPEZ, F. Corporate Boards in OECD Countries: Size, Composition, Functioning and Effectiveness. Corporate Governance: An International Review, v. 13, i. 2, p. 197-210, 2005.

\section{ATHANASAKOU, V.; OLSSON, P. Earnings Quality, Corporate Governance, and Earnings Quality. Working Paper, 2012.}


BAI, C.-E. et al. Corporate governance and market valuation in China. Journal of Comparative Economics, v. 32, i. 4, p. 599-616, 2004.

BAUER, R. et al. The impact of corporate governance on corporate performance: Evidence from Japan. Pacific-Basin Finance Journal, v. 16, i. 3, p. 236-251, 2008.

BOONE, T. et al. Learning and knowledge depreciation in professional services. Management Science, v. 54, i. 7, p. 1231-1236, 2008.

BOS, A. de; DONKER, H. Monitoring Accounting Changes: empirical evidences from the Netherlands. Corporate Governance, v. 12, i. 1, p. 60-73, 2004.

BOUBRAKI, N. et al. Incorporation Law, Ownership Structure, and Firm Value: Evidence from Canada. Journal of Empirical Legal Studies, v. 8, i. 2, p. 358-383, 2011.

BRICK, I. E.; PALMON, O.; WALD, J. K. CEO compensation, director compensation, and firm performance: Evidence of cronyism? Journal of Corporate Finance, v. 12, i. 3, p. 403-423, 2006.

CHANEY, P. K.; FACCIO, M.; PARSLEY, D. The quality of accounting information in politically connected firms. Journal of Accounting and Economics, v. 51, i. 1-2, p. 58-76, 2011.

CHEN, L. Local Institutions, Audit Quality, and Corporate Scandals of US-Listed Foreign Firms. Journal of Business Ethics, p. 351-373, 2016.

CHEN, Y.-M.; GONG, S.-C. Ownership structure and corporate performance: some Chinese evidence. Advances in Pacific Basin Financial Markets, v. 6, p. 177-193, 2000 .

CHOI, B. B.; LEE, D.; PARK, Y. Corporate Social Responsibility, Corporate Governance and Earnings Quality: Evidence from Korea. Corporate Governance: An International Review, v. 21, i. 5, p. 447-467, 2013.

COLES, J. L. et al. Boards: Does one size fit all? Journal of financial economics, v. 87, i. 2, p. 329-356, 2008.

CORREIA, L. F. et al. Um índice de avaliação da qualidade da governança corporativa no Brasil. Revista Contabilidade \& Finanças-USP, v. 22, n. 55, 2011. 
DÂVILA, M.; WATKINS, K. Corporate Governance and Turnovers in México. Working Paper, Universidad Popular Autónoma de Puebla, 2009.

EL SAYED EBAID, I. Corporate governance and investors’ perceptions of earnings quality: Egyptian perspective. Corporate Governance: The International Journal of Business in Society, v. 13, i. 3, p. 261-273, 2013.

FAMA, E. F. Agency Problems and the Theory of the Firm. The Journal of Political Economy, v. 88, i. 2, p. 288-307, 1980.

FAMA, E. F.; JENSEN, M. C. Separation of Ownership and Control Separation of Ownership and Control. Journal of Law and Economics, v. 26, i. 2, p. 301-325, 1983.

GABRIELSEN, G.; GRAMLICH, J. D.; PLENBORG, T. Managerial ownership, information content of earnings, and discretionary accruals in a non-US setting. Journal of Business Finance and Accounting, v. 29, i. 7-8, p. 967-988, 2002.

GANI, L.; JERMIAS, J. Investigating the effect of board independence on performance across different strategies. The International Journal of Accounting, v. 41, i. 3, p. 295-314, 2006.

GILL, A.; MATHUR, N. Factors that influence financial leverage of Canadian firms. Journal of Applied Finance and Banking, v. 1, i. 2, p. 19, 2011.

GUEST, P. M. The impact of board size on firm performance: evidence from the UK. The European Journal of Finance, v. 15, i. 4, p. 385-404, 2009.

GUL, F. A.; SRINIDHI, B.; NG, A. C. Does board gender diversity improve the informativeness of stock prices? Journal of Accounting and Economics, v. 51, i. 3, p. 314-338, 2011.

GUPTA, V. K. et al. The role of gender stereotypes in perceptions of entrepreneurs and intentions to become an entrepreneur. Entrepreneurship theory and practice, v. 33, i. 2, p. 397-417, 2009.

HAZARIKA, S.; KARPOFF, J. M.; NAHATA, R. Internal corporate governance, CEO turnover, and earnings management. Journal of Financial Economics, v. 104, i. 1, p. 44-69, 2012. 
HERMALIN, B. E.; WEISBACH, M. S. Boards of directors as an endogenously. 2003.

HUTCHINSON, M. An analysis of the association between firms' investment opportunities, board composition and firm performance. Asia-Pacific Journal of Accounting \& Economics, v. 9, i. 1, p. 17-38, 2002.

ISIK, O.; INCE, A. R. Board Size, Board Composition and Performance: An Investigation on Turkish Banks. International Business Research, v. 9, i. 2, p. 74, 2016.

JENSEN, M. C.; MECKLING, W. H. Theory of the Firm: Managerial Behavior, Agency Costs and Ownership Structure. Journal of Financial Economics, v. 3, p. 305-360, 1976.

JENSEN, M. C. The modern industrial revolution, exit, and the failure of internal control systems. The Journal of Finance, v. 48, i. 3, p. 831-880, 1993.

JIZI, M. I. et al. Corporate Governance and Corporate Social Responsibility Disclosure : Evidence from the US Banking Sector. Journal of Business Ethics, v. 125, p. 601-615, 2014.

KARAMANOU, I.; VAFEAS, N. The association between corporate boards, audit committees, and management earnings forecasts: An empirical analysis. Journal of Accounting research, v. 43, i. 3, p. 453-486, 2005.

LANG, M. H.; LUNDHOLM, R. J. Voluntary Disclosure and Equity Offerings: Reducing Information Asymmetry or Hyping the Stock? Contemporary Accounting Research, v. 17, i. 4, p. 623-662, 2000.

LA PORTA, R. et al. Law and finance. Journal of political economy, v. 106, i. 6, p. 1113-1155, 1998.

LARCKER, D. F. et al. Corporate governance, accounting outcomes, and organizational performance. The Accounting Review, v. 82, i. 4, p. 963-1008, 2007.

LEE, C. I. et al. Board composition and shareholder wealth: The case of management buyouts. Financial Management, p. 58-72, 1992.

LEFORT, F. Ownership structure and corporate governance in Latin America. Revista Abante, v. 8, i. 1, p. 55-84, 2005. 
LEHN, K. M. et al. Determinants of the size and composition of US corporate boards: 1935-2000. Financial Management, v. 38, i. 4, p. 747-780, 2009.

LEUZ, C.; NANDA, D.; WYSOCKI, P. D. Earnings Management and Investor Protection: An International Comparison. Journal of Financial Economics, v. 69, i. 3, p. 1-32, 2002.

LINCK, J. S. et al. The determinants of board structure. Journal of Financial Economics, v. 87, i. 2, p. 308-328, 2008.

LI, T.; SUN, L.; ZOU, L. State ownership and corporate performance: A quantile regression analysis of Chinese listed companies. China Economic Review, v. 20, i. 4, p. 703-716, 2009.

MACEDO, M. A. da S.; CORRAR, L. J. Análise Comparativa do Desempenho Contábil-Financeiro de Empresas Com Boas Práticas de Governança Corporativa no Brasil. Revista de Contabilidade e Controladoria, v. 4, n. 1, p. 42-61, 2012.

MAK, Y. T.; KUSNADI, Y. Size really matters: Further evidence on the negative relationship between board size and firm value. Pacific-Basin Finance Journal, v. 13, i. 3, p. 301-318, 2005.

MIGUEL, A. de; PINDADO, J.; TORRE, C. de la. Ownership structure and firm value: New evidence from Spain. Strategic Management Journal, v. 25, i. 12, p. 1199-1207, 2004.

MOLLAH, S.; ZAMAN, M. Shari'ah supervision, corporate governance and performance: Conventional vs. Islamic banks. Journal of Banking \& Finance, v. 58, p. 418-435, 2015.

NGUYEN, T. D. H. et al. The effect of temperature on the catalytic conversion of Kraft lignin using near-critical water. Bioresource technology, v. 170, p. 196-203, 2014.

O’CONNELL, V.; CRAMER, N. The relationship between firm performance and board characteristics in Ireland. European Management Journal, v. 28, i. 5, p. 387-399, 2010.

OZCAN, I. S. I. K.; INCE, A. R. Board Size, Board Composition and Performance: An Investigation on Turkish Banks. International Business Research, v. 9, i. 2, p. 74, 2016. 
PEARCE, J. A.; ZAHRA, S. A. Board composition from a strategic contingency perspective. Journal of management studies, v. 29, i. 4, p. 411-438, 1992.

QI, D.; WU, W.; ZHANG, H. Shareholding structure and corporate performance of partially privatized firms: Evidence from listed Chinese companies. Pacific-Basin Finance Journal, v. 8, i. 5, p. 587-610, 2000.

RAJGOPAL, S.; VENKATACHALAM, M. Financial reporting quality and idiosyncratic return volatility. Journal of Accounting and Economics, v. 51, i. 1-2, p. 1-20, 2011.

RODRIGUEZ-FERNANDEZ, M.; FERNANDEZ-ALONSO, S.; RODRIGUEZ-RODRIGUEZ, J. Board characteristics and firm performance in Spain. Corporate Governance, v. 14, i. 4, p. 485-503, 2014.

SÁENZ GONZÁLEZ, J.; GARCÍA-MECA, E. Does Corporate Governance Influence Earnings Management in Latin American Markets? Journal of Business Ethics, v. 121, i. 3, p. 419-440, 2014.

SHIRAI, S. Assessing the impact of financial and capital market reforms on firms' corporate financing patterns in India. South Asia economic journal, v. 5, i. 2, p. 189-208, 2004.

SHIRI, M. M. et al. Corporate Governance and Earning Quality : Evidence from Iran. Middle-East Journal of Scientific Research, v. 11, i. 6, p. 702-708, 2012.

SHLEIFER, A.; VISHNY, R. W. A survey of Corperate Governance. The Journal of Finance, v. 52, i. 2, p. 737-783, 1997.

SILVEIRA, A. D. M. da; BARROS, L. A. B. DE C. Determinantes da Qualidade da Governança Corporativa das Companhias Abertas Brasileiras. REAd-Revista Eletrônica de AdministraçãoJournal of Chemical Information and Modeling, v. 14, n. 3, p. 160, 2008.

SILVEIRA, A. D. M. da et al. Evolution and determinants of firm-level corporate governance quality in Brazil. Revista de Administração, v. 44, i. 3, p. 173-189, 2007.

SILVEIRA, A. D. M. da. Governança Corporativa e Estrutura de Propriedade: Determinantes e Relação com o Desempenho das Empresas no Brasil. 2004. Tese (Doutorado em Administração)-Universidade de São Paulo, São Paulo, 2004. 
SILVEIRA, A. D. M. da; PEROBELLI, F. F. C.; BARROS, L. A. B. de C. Governança Corporativa e os Determinantes da Estrutura de Capital: Evidências Empíricas no Brasil. RAC-Revista de Administração Contemporânea, Curitiba, v. 12, n. 3, p. 763-788, 2008.

STANWICK, P. A.; STANWICK, S. D. The relationship between corporate governance and financial performance: An empirical study of Canadian firms. The Business Review, Cambridge, v. 16, i. 2, p. 35-41, 2010.

SUN, Q.; TONG, W. H. S. China share issue privatization: the extent of its success. Journal of financial economics, v. 70, i. 2, p. 183-222, 2003.

TIAN, L.; ESTRIN, S. Retained state shareholding in Chinese PLCs: does government ownership always reduce corporate value? Journal of Comparative Economics, v. 36, i. 1, p. 74-89, 2008.

WEIR, C. et al. Internal and external governance mechanisms: their impact on the performance of large UK public companies. Journal of Business Finance \& Accounting, v. 29, i. 5 6, p. 579-611, 2002.

XU, X.; WANG, Y. Ownership structure and corporate governance in Chinese stock companies. China economic review, v. 10, i. 1, p. 75-98, 1999.

YEO, G. H. H. et al. Corporate Ownership Structure and the Informativeness of Earnings. Journal of Business, Finance and Accounting, v. 29, i. 7, p. 1023-1046, 2002.

YERMACK, D. Higher market valuation of companies with a small board of directors. Journal of financial economics, v. 40, i. 2, p. 185-211, 1996.

ZIAEE, M. The effect of audit quality on the performance of listed companies in Tehran Stock Exchange. International Letters of Social and Humanistic Sciences, v. 10, i. 1, p. 36-43, 2014. 


\section{Como citar este artigo:}

\section{ABNT}

SILVA, Josimar Pires da et al. Mechanisms of corporate governance and performance: analysis of public companies listed in BM\&FBovespa. RACE, Revista de Administração, Contabilidade e Economia, Joaçaba: Ed. Unoesc, v. 16, n. 3, p. 1161-1184, set./dez. 2017. Disponível em: <http://editora.unoesc.edu.br/index.php/ race>. Acesso em: dia/mês/ano.

\section{APA}

Silva, J. P. da, Bonfim, M. P., Noriller, R. M., \& Berner, C. V. (2017). Mechanisms of corporate governance and performance: analysis of public companies listed in BM\&FBovespa. RACE, Revista de Administração, Contabilidade e Economia, 16(3), 11611184. Recuperado em dia/mês/ano, de http://editora.unoesc.edu.br/index.php/race 
